\title{
Tingkat Pengetahuan Dengan Perilaku Warga Dalam Menjalankan Protokol Kesehatan di Masa New Normal Pandemi Corona
}

\author{
Yehuda Imanuel Widyakusuma Putra ${ }^{1}$, Novita Verayanti Manalu ${ }^{2}$ \\ ${ }^{1}$ Mahasiswa Program Studi Sarjana Ilmu Keperawatan Universitas Advent Indonesia \\ ${ }^{2}$ Dosen Program Studi Sarjana Ilmu Keperawatan Universitas Advent Indonesia \\ Alamat Korespondensi : Yehuda2809@gmail.com; verayantimanalu@unai.edu
}

\begin{abstract}
Abstrak
COVID-19 telah menjadi masalah kesehatan dunia pada tahun 2020. Penyakit ini hingga kini belum ada obat untuk menyembuhkannya. Cara terbaik untuk mencegah penyakit ini adalah dengan memutus mata rantai penyebaran Covid-19 melalui isolasi. Namun pembatasan aktivitas masyarakat membuat perekonomian masyarakat menjadi menurun. Untuk mencegah hal ini terus berlanjut masyarakat harus mulai beradaptasi dengan kebiasaan hidup baru atau disebut dengan 'new normal life'. Dengan diberlakukannya new normal, masyarakat harus melakukan aktifitas di luar rumah dengan tetap mematuhi protokol kesehatan yang telah diatur oleh pemerintah. Penelitian ini bertujuan untuk mengidentifikasi tingkat pengetahuan masyarakat tentang Covid-19, perilaku warga dalam menjalankan protocol kesehatan di masa new normal, dan untuk mengetahui apakah ada hubungan yang signifikan antara kedua variable tersebut. Penelitian ini dilakukan menggunakan metode deskriptif kuantitatif dengan pendekatan survey. Populasinya adalah masyarakat yang tinggal di SK 14/31 Kelurahan Batu Gantung, Nusaniwe, Kota Ambon dengan jumlah sampel 50 orang. Pengumpulan data dilakukan dengan menyebarkan kuesioner pengetahuan dan perilaku. Data dianalisis menggunakan analisis korelasi spearman dengan perangkat lunak SPSS. Didapati bahwa tingkat pengetahuan masyarakat tentang Covid-19 termasuk dalam kategori tinggi (52\%). Dan untuk perilaku masyarakat berada pada kategori baik (78\%). Terdapat hubungan bermakna antara pengetahuan dengan perilaku masyarakat tentang Covid 19 dengan p-value 0,065 .
\end{abstract}

Kata kunci : Covid-19, New normal, Pengetahuan, Perilaku

\begin{abstract}
COVID-19 has become a global health problem in 2020. Until now, there is no cure for this disease. The best way to prevent this disease is to break the chain of spread of Covid-19 through isolation. However, restrictions on community activities have made the people's economy decline. To prevent this from happening, people must begin to adapt to new life habits or what is called the 'new normal life'. With the enactment of the new normal, people must carry out activities outside the home while adhering to health protocols that have been regulated by the government. This study aims to identify the level of public knowledge about Covid-19, the behavior of residents in carrying out health protocols in the new normal period, and to find out whether there is a significant relationship between the two variables. This research was conducted using a quantitative descriptive method with a survey approach. The population is the people who live in SK 14/31 Batu Gantung Village, Nusaniwe, Ambon City with a sample size of 50 people. Data collection was carried out by distributing knowledge and behavior questionnaires. Data were analyzed using Spearman correlation analysis with SPSS software. It was found that the level of public knowledge about Covid-19 was in the high category (52\%). And people's behavior is in the good category (78\%). There is a significant relationship between knowledge and people's behavior about the Covid-19 health protocol with a p-value of 0.065 .
\end{abstract}

Keywords: Covid-19, New normal, Knowledge, Behavior 


\section{PENDAHULUAN}

Corona virus disease -19 atau yang lebih populer dengan istilah COVID-19 saat ini menjadi sorotan dan sangat penting untuk mendapat perhatian dari masyarakat di seluruh dunia. Coronavirus merupakan keluarga besar virus yang menyebabkan penyakit pada manusia. Pada manusia biasanya menyebabkan penyakit infeksi saluran pernapasan, mulai flu biasa hingga penyakit yang serius seperti Middle East Respiratory Syndrome (MERS) dan Sindrom Pernafasan Akut Berat/ Severe Acute Respiratory Syndrome (SARS). Coronavirus jenis baru yang ditemukan pada manusia sejak kejadian luar biasa muncul di Wuhan Cina, pada Desember 2019, kemudian diberi nama Severe Acute Respiratory Syndrome Coronavirus 2 (SARS-COV2), dan menyebabkan penyakit Coronavirus Disease-2019 (COVID-19) (covid.kemkes.go.id).

Pada bulan September 2020, secara global kasus covid sebanyak 27.288.585 kasus dengan 887.549 kasus kematian (worldometers, 2020). Di Indonesia, penambahan jumlah kasus terkonfirmasi terus meningkat, dimana pada bulan September masih berada pada angka 194.109 kasus dengan 8.025 meninggal dunia (worldometers, 2020). Sementara itu di provinsi Maluku di kota Ambon kasus covid terkonfirmasi sebanyak 1.561 dengan kasus kematian sebanyak 26 orang (ambon.go.id 2020).

Cara terbaik untuk mencegah penyakit ini adalah dengan memutus mata rantai penyebaran Covid-19 melalui isolasi, deteksi dini dan melakukan proteksi dasar yaitu melindungi diri dan orang lain dengan cara sering mencuci tangan dengan air mengalir dan sabun atau menggunakan hand sanitizer, menggunakan masker dan tidak menyentuh area muka sebelum mencuci tangan, serta menerapkan etika batuk dan bersin yang benar (Dirjen P2P Kemkes RI, 2020). Namun pembatasan aktivitas masyarakat berpengaruh pada aktivitas bisnis yang kemudian berimbas pada perekonomian. Laporan Badan Pusat Statistik (BPS) Agustus ini menyebut bahwa pertumbuhan ekonomi Indonesia pada kuartal II 2020 minus 5,32 persen begitu juga seterusnya. Sebelumnya, pada kuartal I 2020, BPS melaporkan bahwa pertumbuhan ekonomi Indonesia hanya tumbuh sebesar 2,97 persen, turun jauh dari pertumbuhan sebesar 5,02 persen pada periode yang sama 2019 lalu (Kompas.com 2020).

Untuk wilayah provinsi Maluku pertumbuhan ekonomi triwulan II 2020 tercatat negatif $0,92 \%$, turun dibandingkan dengan capaian pada triwulan I sebesar 4,01\% (malukuterkini. com). Untuk mencegah hal ini terus berlanjut masyarakat harus mulai beradaptasi dengan kebiasaan hidup baru atau disebut dengan 'new normal life'. New normal adalah perubahan perilaku untuk tetap melakukan aktivitas normal dengan ditambah menerapkan protokol kesehatan guna mencegah terjadinya penularan Covid-19. Secara sederhana, new normal ini hanya melanjutkan kebiasaan-kebiasaan yang selama ini dilakukan saat diberlakukannya karantina wilayah atau Pembatasan Sosial Berskala Besar (PSBB) (djkn.kemenkeu.go.id).

Dengan diberlakukannya new normal, masyarakat harus melakukan aktifitas di luar rumah dengan tetap mematuhi protokol kesehatan yang telah diatur oleh pemerintah, yaitu memakai masker bila keluar dari rumah, sering mencuci tangan dengan sabun, dan tetap menjaga jarak serta menghindari kerumunan orang untuk mencegah penularan virus corona. Upaya 
pemutusan mata rantai covid-19 di era new normal ini memerlukan pemahaman dan pengetahuan yang baik dari seluruh elemen termasuk masyarakat. Pengetahuan adalah informasi yang telah dikombinasikan dengan pemahaman dan potensi untuk menindaki, yang lantas melekat di benak seseorang (Wikipedia.org).

Pengetahuan juga merupakan domain terpenting dalam terbentuknya perilaku (Donsu, 2017). Perilaku adalah tanggapan atau reaksi individu terhadap rangsangan atau lingkungan (KBBI, 2014). Perilaku juga adalah sebagian tindakan seseorang yang dapat dipelajari dan diamati. Salah satu factor yang mempengaruhi perilaku manusia atau masyarakat adalah tingkat pengetahuan (Donsu, 2017). Di Indonesia dalam kasus covid-19 di era new normal, pengetahuan masyarakat tentang protokol kesehatan sangat diperlukan sebagai dasar masyarakat dalam menunjukan perilaku pencegahan covid19. Pada penelitian ini, akan dicari hubungan tingkat pengetahuan masyarakat Kota Ambon tentang Covid19 dengan perilaku masyarakat dalam menjalankan protocol kesehatan sebagai upaya pencegahan penularan Covid-19.

Tujuan penelitian ini untuk mengetahui gambaran karateristik, tingkat pengetahuan, perilaku masyarakat, dan hubungan antara pengetahuan dengan perilaku masyarakat Kota Ambon dalam menjalankan protokol kesehatan di masa new normal pandemi corona.

\section{METODE}

Penelitian ini dilakukan
menggunakan metode deskriptif
kuantitatif dengan pendekatan survey.
Sampel penelitian diambil secara Area
Sampling yaitu tiap perwakilan dari
rumah warga di SK 14/31 Kelurahan

Batu Gantung, Nusaniwe, Kota Ambon, dengan sampel sebanyak 50 responden. Pengambilan sampel dilakukan menggunakan kuesioner yang disebarkan ke rumah warga. Instrument yang digunakan berupa kuesioner yang terdiri dari karateristik,pengetahuan dan perilaku.

Karateristik responden meliputi usia, jenis kelamin, tingkat Pendidikan dan jenis pekerjaan. Sedangkan kuesioner pengetahuan tentang Covid-19 berisi 10 pertanyaan yang disertai alternative jawaban benar dan salah. Jawaban yang benar mendapat nilai 1 dan nilai 0 untuk jawaban yang salah. Untuk kuesioner perilaku terdiri atas 7 pertanyaan dengan kriteria hasil terbagi atas 3 kategori yaitu baik,cukup baik dan kurang baik. Analisis data dilakukan secara univariat dan bivariate.Analisis univariat dilakukan pada masing masing variabel sedangkan analisi bivariate menggunakan analisis korelasi Spearman.

\section{HASIL PENELITIAN}

Responden yang turut berpartisipasi pada penelitian ini adalah berjumlah 50 orang. Responden ini adalah masyarakat yang tinggal di SK 14/31 Kelurahan Batu Gantung, Nusaniwe, Kota Ambon, dan bersedia untuk mengisi kuesioner. Tabel 1 menunjukkan karakteristik responden yang meliputi usia, jenis kelamin, pendidikan, dan pekerjaan. Berdasarkan Tabel 1 didapati bahwa responden yang berusia 17-25 tahun adalah responden terbanyak yaitu sebanyak 18 orang $(36 \%)$. Berdasarkan karateristik, responden yang paling banyak adalah jenis kelamin perempuan yaitu berjumlah 27 orang (54\%) dan laki-laki berjumlah 23 orang (46\%). Pendidikan terakhir responden yang terbanyak adalah SMA/SMK (58\%) serta untuk 
pekerjaan responden adalah siswa perguruan tinggi (26\%).

Tabel 1. Karateristik Responden

\begin{tabular}{llcc}
\hline \multicolumn{1}{c}{ Variabel } & \multicolumn{1}{c}{ Kategori } & N & $\mathbf{\%}$ \\
\hline Usia & $17-25$ & 18 & 36.0 \\
& $26-35$ & 17 & 34.0 \\
& $36-45$ & 8 & 16.0 \\
& $46-55$ & 5 & 10.0 \\
& $56-65$ & 2 & 4.0 \\
Jenis Kelamin & & & \\
& Laki laki & 23 & 46.0 \\
\multirow{3}{*}{ Pendidikan Terakhir } & Perempuan & 27 & 54.0 \\
& & & \\
& SD & 0 & 0 \\
& SMP & 3 & 6.0 \\
& SMA/SMK & 29 & 58.0 \\
& DIPLOMA 1/2/3 & 7 & 14.0 \\
& S1 & 11 & 22.0 \\
& S2/S3 & 0 & 0 \\
& & & \\
& Siswa SMA & 2 & 4.0 \\
& Siswa Perguruan Tinggi & 13 & 26.0 \\
& PNS & 8 & 16.0 \\
& Pegawai Swasta & 10 & 20.0 \\
& Wiraswasta & 7 & 14.0 \\
& D11 & 10 & 20.0 \\
\hline & & &
\end{tabular}

Tabel 2. Tingkat Pengetahuan

\begin{tabular}{cccc}
\hline No & Kategori & N & \% \\
\hline 1. & Tinggi & 26 & 52.0 \\
2. & Sedang & 24 & 48.0 \\
3. & Rendah & 0 & 0 \\
\hline
\end{tabular}

Hasil penelitian menunjukkan pengetahuan masyarakat tentang Covid19 SK 14/31 Kelurahan Batu Gantung, Nusaniwe, Kota Ambon berada pada kategori tinggi (52\%) dan terdapat $48 \%$ masyarakat yang berada pada kategori sedang.

Tabel 3. Perilaku Masyarakat

\begin{tabular}{cccc}
\hline No & Kategori & $\mathbf{N}$ & \% \\
\hline 1. & Baik & 39 & 78.0 \\
2. & Cukup Baik & 11 & 22.0 \\
3. & Kurang Baik & 0 & 0 \\
\hline
\end{tabular}

Untuk perilaku masyarakat terkait protocol kesehatan Covid-19, masyarakat menunjukkan perilaku yang baik sebanyak $78 \%$ dan hanya $22 \%$ masyarakat berperilaku cukup baik. 
Tabel 4. Hubungan Tingkat Pengetahuan dengan Perilaku Dalam Menjalankan Protokol Kesehatan di Masa New Normal Pandemi Corona

\begin{tabular}{llllllll}
\hline \multicolumn{1}{c}{ Pengetahuan } & \multicolumn{7}{c}{ Perilaku } \\
& Baik & \multicolumn{7}{c}{ Cukup baik } & Total & & P value $(0,05)$ \\
Tinggi & $n$ & $\%$ & $n$ & $\%$ & $\mathrm{~N}$ & $\%$ & \\
Sedang & 23 & 88,5 & 3 & 11,5 & 26 & 52,0 & 0,065 \\
Total & 16 & 66,7 & 8 & 33,3 & 24 & 48,0 & \\
\hline
\end{tabular}

Hubungan signifikan dengan $p$-value $<0,05$

Dan berdasarkan tabel memperlihatkan bahwa hasil uji statistik diperoleh $p$-value $=0.065$ yang berarti $<0,05$, maka dapat disimpulkan bahwa tingkat pendidikan responden memiliki hubungan yang signifikan terhadap perilaku dalam menjalankan protokol kesehatan seperti yang ditunjukkan pada tabel 4.

\section{Pembahasan}

Hasil uji statistik menunjukan bahwa tingkat pengetahuan responden memiliki hubungan yang signifikan terhadap perilaku dalam menjalankan protokol kesehatan ( $p$-value $=0.065)$. Hasil penelitian ini sejalan dengan hasil penelitian Ika, P dan Anisa, E, R. (2020) di wilayah Kabupaten Wonosobo. Pada penelitiannya ditemukan bahwa terdapat hubungan bermakna antara pengetahuan dengan perilaku masyarakat tentang Covid-19. Perilaku manusia terbagi menjadi tiga yaitu kognitif, afektif, dan psikomotor yang dalam perkembangannya dimodifikasi untuk pengukuran hasil pendidikan kesehatan yakni pengetahuan, sikap dan praktek atau tindakan. Pengetahuan merupakan faktor yang sangat penting dalam membentuk tindakan seseorang. Setelah seseorang mengalami stimulus atau objek kesehatan, kemudian mengadakan penilaian atau pendapat terhadap apa yang diketahui, proses selanjutnya yang diharapkan melaksanakan atau mempraktekkan apa yang diketahui dan disikapinya, sehingga dapat dikatakan bahwa seseorang yang mempunyai pengetahuan tinggi akan mempunyai perilaku yang lebih baik dari pada orang yang mempunyai pengetahuan rendah (Notoatmodjo, 2003). Sehingga dapat disimpulkan bahwa masyarakat dengan tingkat pengetahuan tinggi cenderung memiliki kemungkinan yang lebih besar untuk melakukan perilaku yang baik.

Upaya pemutusan mata rantai penyebaran Covid-19 memang memerlukan pemahaman dan pengetahuan yang baik dari seluruh elemen masyarakat. Pengetahuan yaitu sesuatu yang ditangkap melalui panca indera yakni penglihatan, pendengaran, penciuman, perabaan dan perasaan terhadap suatu obyek sehingga mampu dimengerti dan dipahami seseorang. Pengetahuan adalah suatu hasil dari rasa ingin tahu melalui proses sensoris, terutama pada mata dan telinga terhadap objek tertentu (Donsu, 2017). Pengetahuan tentang Covid 19 pada masyarakat Kota Ambon menunjukkan pengetahuan yang tinggi.Hasil penelitian ini sejalan dengan hasil penelitian yang dilakukan oleh Yanti B, dkk (2020) yang menyebutkan bahwa 99\% masyarakat Indonesia mempunyai pengetahuan yang baik, 59\% mempunyai sikap yang positif dan 93\% mempunyai perilaku yang baik terhadap upaya pencegahan Covid-19 di Indonesia dengan social distancing. 
Masyarakat yang memiliki pengetahuan baik juga memiliki sikap dan perilaku yang baik pula. Pengetahuan masyarakat di Kota Ambon yang tinggi tentang Covid-19 ini berpengaruh terhadap perilaku mereka dalam pencegahan penyakit Covid-19. Menurut (Sulistyaningtyas, 2020) Pengetahuan yang baik dapat didukung oleh penerimaan terhadap informasi yang beredar di masyarakat tentang Covid 19. Seseorang yang telah mengetahui tentang suatu informasi tertentu, maka dia akan mampu menentukan dan mengambil keputusan bagaiman dia harus menghadapinya. Dengan kata lain, saat seseorang mempunyai informasi tentang Covid-19, maka ia akan mampu untuk menentukan bagaimana dirinya harus berperilaku terhadap Covid-19 tersebut (Ahmadi,2013). Berdasarkan hasil penelitian, pengetahuan masyarakat yang masih perlu ditingkatkan antara lain tentang pemahaman masyarakat yang masih mempercayai bahwa hanya lansia yang dapat terinfeksi oleh virus Covid-19. Menurut (Tiodora, 2020) Semua orang sebenarnya berpotensi terinfeksi Virus Corona namun beberapa kelompok orang tertentu memiliki tingkat risiko yang lebih tinggi untuk terpapar Virus Corona hingga bisa membawa kepada kematian. Meskipun data menunjukkan beberapa kelompok tertentu misalnya kelompok muda memiliki daya tahan tubuh yang lebih baik dibanding kelompok lansia dan penderita penyakit kronis, namun bukan berarti kelompok muda tidak mungkin terkena. Bisa saja kelompok muda sudah terinfeksi namun tidak menunjukkan gejala seperti demam $>38^{\circ} \mathrm{C}$, batuk dan sesak nafas. Sebagaimana dinyatakan oleh dr. Jatu Aphridasri seorang dokter spesialis paru bahwa Virus Corona dapat menyerang siapa saja mulai dari bayi, anak- anak, orang dewasa hingga lansia. Artinya semua orang harus mewaspadai peyakit Covid-19 ini agar penyebaran virus dapat diredam dan dihentikan (Tiodora, 2020).

Untuk itu edukasi sangat diperlukan untuk memperbaiki persepsi masyarakat yang masih kurang tepat. Menurut (Olum R,Chekwueh dkk, 2020) pendidikan professional berkelanjutan diperlukan untuk meningkatkan pengetahuan dan mengubah sikap negative serta meningkatkan praktik pencegahan dan pengobatan. Kemudian Perilaku yang baik juga dapat menjadi upaya pencegahan terhadap penularan Covid 19 (Audria, 2019). Sebaliknya perilaku masyarakat yang tidak baik akan meningkatkan jumlah kasus dan angka kematian akibat penularan covid-19 (Simbolon, 2020).

Penelitian ini menunjukkan sebanyak 78\% masyarakat SK 14/31 Kelurahan Batu Gantung, Nusaniwe, Kota Ambon mempunyai perilaku yang baik dalam menjalankan protocol kesehatan. Namun analisis data menunjukkan bahwa ada beberapa perilaku yang berada dalam tingkat kepatuhan rendah. Salah satunya adalah mencuci tangan. Dalam penelitian ini didapati bahwa sebagian besar masyarakat sudah melakukan perilaku mencuci tangan, namun hanya sebagian yang mencuci tangan sesuai protokol WHO. Padahal cuci tangan adalah salah satu cara yang efektif untuk membunuh kuman termasuk virus Covid19. Didentifikasi bahwa virus Covid-19 dapat menempel pada bagian tubuh terutama tangan yang menyentuh benda yang sudah tertular oleh droplet (Albeth, 2020).

Penelitian lain menunjukkan hanya 50,46\% kepatuhan cuci tangan dengan sabun (Demsa, 2020). Salah satu 
faktor yang mempengaruhi tingkat kepatuhan cuci tangan adalah faktor usia, adanya peningkatan usia, kepatuhan untuk cuci tangan menurun (Ta'adi, dkk, 2019). Kepatuhan merupakan perilaku yang positif dari masyarakat. Sebaliknya perilaku masyarakat yang tidak baik akan meningkatkan jumlah kasus dan angka kematian akibat penularan covid-19 (Demsa, 2020).

Menurut teori Model PengetahuanSikap-Perilaku, pengetahuan merupakan faktor esensial yang dapat mempengaruhi perubahan perilaku, dan individu dapat memperoleh pengetahuan dan ketrampilan melalui proses belajar (Liu et al, 2016). Oleh karena itu pengetahuan masyarakat yang masih kurang dan perilaku masyarakat yang masih berada dalam tingkat kepatuhan yang rendah dapat diupayakan dengan kegiatan sosialisasi melalui edukasi dan pembelajaran oleh pihak-pihak terkait. Dalam masyarakat, peran petugas kesehatan sangat penting untuk sosialisasi dan melakukan pemantauan di masyarakat dalam pencegahan Covid-19.

\section{KESIMPULAN DAN SARAN}

Kesimpulan yang didapat dari penelitian ini adalah bahwa pengetahuan masyarakat di SK 14/31 Kelurahan Batu Gantung, Nusaniwe, Kota Ambon tentang Covid-19 berada pada kategori tinggi dan perilaku masyarakat tentang protocol kesehatan Covid-19 pada kategori baik. Namun di samping itu, masyarakat dinilai masih memiliki potensi Kasus Covid-19 yang rendah berdasarkan beberapa pemahaman yang salah dan perilaku yang kurang tepat dalam pelaksanaannya. Sehendaknya, dengan pengetahuan masyarakat yang baik diharapkan dapat meningkatkan perilaku masyarakat dalam menerapkan protokol kesehatan di masa pandemi
Covid-19 dan juga perlu ada kesadaran dari masyarakat sendiri untuk mentaati protokol kesehatan dimasa pandemi Covid-19. Selain itu peran petugas kesehatan sangat dibutuhkan untuk sosialisasi dan melakukan pemantauan di masyarakat dalam pencegahan Covid19.

\section{DAFTAR PUSTAKA}

Ahmadi (2013). Kesehatan Masyarakat, teori dan aplikasi. Jakarta: Raja Grafindo

Albeth, W dan Idauli, S. (2020). Hubungan Tingkat Pengetahuan tentang Covid-19 Terhadap Kepatuhan Program Lockdown Untuk Mengurangi Penyebaran Covid-19 di Kalangan Mahasiswa Berasrama Universitas Advent Indonesia. Nutrix jurnal . 4 (1).

Audri, O. (2019). Hubungan Pengetahuan dan Sikap Terhadap Perilaku Cuci Tangan pada Masyarakat Kelurahan Pegirian, Jurnal Promkes : The Indonesian Journal of Health Promotion And Health Education, vol 7 No, 1(2019)1-11 DOI: 10.20473/jpk.V7.11.2019.1-11

Demsa, S. (2020). Kepatuhan Civitas Akademik Poltekkes Kemenkes Bengkulu Mengikuti Perauran Pemerintah Dalam Pencegahan penularan Virus Covid-19: Diakses online dari : http://sinta.ristekbrin.go.id/covid/penelitian/detai $\underline{1 / 403}$

Donsu, J, D, T. (2017). Psikologi Keperawatan. Yogyakarta : Pustaka Baru Press. Cetakan I

Ika, P dan Anisa, E, R. (2020). Tingkat Pengetahuan dan Perilaku Masyarakat Kabupaten Wonosobo Tentang Covid-19. Diakses online dari https://ojs.unsiq.ac.id/index.php/jik/article/view/131 $\underline{1 / 783 \text { pada tanggal } 1 \text { oktober } 2020}$

Jawahir, G. (2020). Pandemi Covid-19, Apa Saja Dampak pada Sektor Ketenagakerjaan Indonesia?. Diakses online dari https://www.kompas.com/tren/read/2020/08/11/1 02500165/pandemi-covid-19-apa-saja-dampakpada-sektor-ketenagakerjaan-indonesia-?page $=$ all

Kementrian Kesehatan Republik Indonesia 
(2020). Tanya Jawab Corona Disease ( Covid-19 ) Update 8 Maret 2020. Diakses online dari https://covid19.kemkes.go.id/situasi-infeksiemerging/info-corona-virus/tanya-jawabcoronavirus-disease-covid-19-qna-update-6maret-2020/\#Apakah_Coronavirus dan_COVID19 itu

Kementrian Keuangan Republik Indonesia (2020). New Normal di Tengah Pandemi Covid19. Diakses online dari https://www.djkn.kemenkeu.go.id/kpknlsidempuan/baca-artikel/13169/New-Normal-diTengah-Pandemi-Covid-19.html

Liu, L. et al. (2016). 'Use of a knowledgeattitudebehaviour education programmefor Chinese adults undergoing maintenance haemodialysis: Randomized controlled trial', The Journal of international medical research. 2016/03/07. SAGE Publications, 44(3), pp. 557-568. DOI: 10.1177/0300060515604980.

Noviarsano, M. (2020). Covid-19 Pengaruhi Pertumbuhan Ekonomi Maluku Triwulan II. Diakses online dari https://www.malukuterkini.com/2020/08/10/covi d-19-pengaruhi-pertumbuhan-ekonomi-malukutriwulan-ii/

Olum R, Chekwech G et al. (2020). Coronavirus Disease-2019: Knowledge, Attitude, and Practices of Health Care Workers at Makerere University Teaching Hospitals, Uganda. Original Research Article, Front. Public Health, 30 April 2020

Ramidah, K. (2020). New Normal di Tengah Pandemi Covid-19. Diakses online dari https://www.djkn.kemenkeu.go.id/kpknlsidempuan/baca-artikel/13169/New-Normal-diTengah-Pandemi-Covid-19.html

Sari, D.P, dan Atiqoh, N.S. (2020). Hubungan Antara Pengetahuan Masyarakat Dengan Kepatuhan Penggunaan Masker Sebagai Upaya Pencegahan Penyakit Covid-19 Di Ngoronggah. Rekam Medis dan Informasi Kesehatan, Fakultas Kesehatan, Universitas Duta Bangsa

Sulistyaningtyas, Tri. (2020). Informasi Wabah Virus Covid-19: Kuasa Pengetahuan dan Kelas Sosial, https://sinta.ristekbrin.go.id/covid/pen elitian/detail/80, publish: 2020, Institut Teknologi Bandung, diakses 28 september 2020

Ta'adi, Erni Setyorini, Rifqi Amalya. (2019). Faktor yang Berhubungan dengan Kepatuhan Cuci Tangan 6 Langkah Momen Pertama pada Keluarga Pasien di Ruang Anak, Jurnal Ners dan Kebidanan, Volume 6, Nomor 2, Agustus 2019, hlm. 203-210: DOI: 10.26699/jnk.v6i2.ART.p203-210

World Health Organization (2020). Corona Virus. Diakses online dari https://www.who.int/healthtopics/coronavirus\#tab $=\mathrm{tab} \_3 \mathrm{p}$

Worldometer (2020). COVID-19 Corona virus Pandemic. Diakses Online dari https://www.worldometers.info/corona

Yanti, dkk. (2020). Community Knowledge, Attitudes, And Behavior Towards Social Distancing Policy As Prevention Transmission Of Covid-19 In Indonesia, JAKI (Jurnal Administrasi Kesehatan indonesia) 